\title{
Looking at the Effects of Language Contact With Hakka as Reflected by the Characteristics of the Pingshan Zhanmi Dialect in Shenzhen
}

\author{
Lau Chun-Fat, Zhou Jiafan \\ Department of Chinese, Xiamen University, Fujian, China
}

\begin{abstract}
The special Economic Zone of Shenzhen has been endowed with plentiful of language resources. Apart from various Yue dialects in the west and Hakka dialect in the east, there are also many indigenous Chinese dialects such as the Dapeng dialect (大鹏话), the Danjia dialect (疍家话) and also the Zhanmi dialect (占米话). The last one is not ever reported. Out of curiosity, we went to investigate the dialect which is spoken in isolate patches in the easternmost townships of Pingshan (坪山), Kengzi (坑梓) and Pingdi (坪地). The Pingshan Zhanmi dialect (PZD) seems to be an intermediate between Yue and Hakka dialects. According to our observation, PZD is quite similar to the Dongguan-Baoan Yue dialects (DBYD, 莞宝片奥语) in the western part of the city and has obvious correspondence with them, such as having the onset [m] in the Middle Chinese (MC) Wei (微) characters, little literal/colloquial discrepancies in the Fei Group (非组), [a/e] contrast, literal/colloquial readings in the Geng rime group all with $[\mathrm{y} / \mathrm{k}]$ as codas, etc. However, because of long term contact with the surrounding Hakka dialects, PZD has also a lot of characteristics of Hakka, such as aspirated readings in all MC voiced stops and affricates onsets after devoicing, lack of rounded frontal vowels, no Ying-yang contrast in the Shang tone. More influences of Hakka can be found in the vocabulary, which PZD has been borrowing for centuries.
\end{abstract}

Keywords: Yue dialects, Hakka dialects, Zhanmi dialect, language contact

\section{Introduction}

Pingshan district lies at the northeastern edge of Shenzhen, adjacent to Huizhou city (惠州市). To the west it is next to Henggang (横岗) and Longgang (龙岗), to the South Kuichong (葵涌) and Yantian (盐田) and the north is Kengzi (坑梓) (Baoan County Regional Data, 1997).

According to historical data, people moved to Pingshan from the northern part of China about a millennium ago and named the hill there Dongtoulingshan (东头岭山). Around 1700, Hakka people from northeastern Guangdong began to immigrate and settled first in Laowei (老围) and Luowu (骆屋). Later these combined to become Pingshanwei (坪山围). Then more people came and settled there and became a Pingshan Market (坪山圩) at the beginning of the nineteenth century (Shenzhen History Working Committee, 1996).

As Hakka is the dominant language of eastern Shenzhen, Pingshan is no exception. The PZD dialect is now vanishing, spoken only among older speakers in the villages with surname $\mathrm{Wu}$ (吴) in the Tiantou (田头)

Lau Chun-Fat, D. Sc., Ph.D., Professor, Department of Chinese, Xiamen University.

Zhou Jiafan, MA Student, Department of Chinese, Xiamen University. 
community; and surnames Xu (许), Ye (叶) in the Tianxin (田心) community. Because of these, PZD is also known locally as the Tiantou speech and Tianxin speech. According to the genealogy of the Wu family in Tiantou, their ancestors came around the end of the Song Dynasty from Jiangsu to Dongguan (东莞), and moved at the end of the Ming Dynasty (around 1600) to the present address. They belong to the group of Yue speakers who arrived a bit earlier than the Hakka people, who came there at the first half of the 18th century. The latter out-numbered them and Hakka became the popular dialect there (Baoan County Regional Data, 1997).

According to our informant, these villagers have a heart to preserve their own dialect since generations. As the Pingshan area is dominated by Hakka, the PZD speakers use Hakka outside of their home, but always keep on speaking their dialect in their village area. When they worship their ancestors, those who cannot speak PZD are not allowed to join the family banquet. This is why they sometimes name their dialect as Zugonghua (祖公 话), or ancestral tongue. The neighboring Hakka people do not speak their dialect, or even do not know its existence.

In this study, our informant, Mr. YT Wu was born in 1933, and was 81 years old when we interviewed him in 2011. He finished nine years of education. He learned to read and write in the Zhanmi dialect when he was young. In 1945 he went to Longang to further his education in the Hakka dialect, and has been teaching in Danshui (淡水) until retirement. He was using PZD with his parents, and is still speaking in this dialect with his younger sisters.

\section{Phonology of the Pingshan Zhanmi Dialect}

\section{Onsets (With Chinese Characters as Examples)}

\begin{tabular}{|l|l|l|l|l|}
\hline $\mathrm{p}$ 布玻并捧 & $\mathrm{ph}$ 辈破部符 & $\mathrm{m}$ 马雾慢袜 & $\mathrm{f}$ 否服火华 & $\mathrm{v}$ 无卫匀挖 \\
\hline $\mathrm{t}$ 多队诞得 & th 堤兔定敌 & & & 1 努劳嫩力 \\
\hline $\mathrm{ts}$ 左沾诈质 & tsh 且耻创植 & & $\mathrm{s}$ 苏使商舌 & \\
\hline $\mathrm{k}$ 家楷坚割 & $\mathrm{kh}$ 苦奇舅刻 & $\mathrm{n}$ 吴肴纽硬 & $\mathrm{h}$ 虾豪糠喝 & \\
\hline & & $\mathrm{n}$ 女惹严月 & ø 亚矮安鸭 & $\mathrm{j}$ 爷有英日 \\
\hline
\end{tabular}

Notes:

1. PZD has 18 onsets, including the zero onset [ǿ].

2. It has no nasal onset [n]. Characters spoken with the [n] onset in Mandarin are spoken with[1] or [n], but the latter is limited only to a few characters.

3. PZD has only one set of sibilants, [ts, tsh, s], pronounced the same as Hakka or Cantonese.

4. [v] is a labiodental fricative, which more or less corresponds to Cantonese [w].

5. [j] almost has the same origin as Cantonese [j], but tends to be pronounced as [z] if the vowel following is [i]. However, as it does not form a contrast, we treat it as an allophone.

\section{Rimes}

\begin{tabular}{|c|c|c|c|c|c|}
\hline $\begin{array}{l}\text { a } \\
\text { 巴家遮野 }\end{array}$ & $\begin{array}{l}\text { ai } \\
\text { 大再排鞋 }\end{array}$ & $\begin{array}{l}\text { au } \\
\text { 袍遭高吵 }\end{array}$ & & $\begin{array}{l}\mathrm{ei} \\
\text { 祭米鸡桂 }\end{array}$ & $\begin{array}{l}\mathrm{eu} \\
\text { 头走浮秋 }\end{array}$ \\
\hline $\begin{array}{l}\text { am } \\
\text { 贪蓝斩咸 }\end{array}$ & $\begin{array}{l}\text { an } \\
\text { 凡丹山限 }\end{array}$ & $\begin{array}{l}\text { an } \\
\text { 生耕影营 }\end{array}$ & $\begin{array}{l}\text { em } \\
\text { 林侵今饮 }\end{array}$ & $\begin{array}{l}\text { en } \\
\text { 吞亲伦墩 }\end{array}$ & $\begin{array}{l}\text { en } \\
\text { 灯英整星 }\end{array}$ \\
\hline $\begin{array}{l}\text { ap } \\
\text { 答蜡插夹 }\end{array}$ & $\begin{array}{l}\text { at } \\
\text { 擦八瞎末 }\end{array}$ & $\begin{array}{l}\text { ak } \\
\text { 白客摘革 }\end{array}$ & $\begin{array}{l}\text { ep } \\
\text { 笠执级吸 }\end{array}$ & $\begin{array}{l}\text { et } \\
\text { 笔七骨出 }\end{array}$ & $\begin{array}{l}\mathrm{ek} \\
\text { 德食责席 }\end{array}$ \\
\hline \multirow[t]{2}{*}{$\begin{array}{l}0 \\
\text { 课俊错锄 }\end{array}$} & $\begin{array}{l}\text { on } \\
\text { 帮广放江 }\end{array}$ & $\begin{array}{l}\text { ək } \\
\text { 作勺郭镬 }\end{array}$ & & $\begin{array}{l}\text { on } \\
\text { 龙冬凤勇 }\end{array}$ & $\begin{array}{l}\text { ok } \\
\text { 独酷祝属 }\end{array}$ \\
\hline & & & & $\varepsilon \eta$ & $\varepsilon \mathrm{k}$ \\
\hline
\end{tabular}




\begin{tabular}{|c|c|c|c|c|c|}
\hline & & & & 增弘孟 & 克肋测碧 \\
\hline 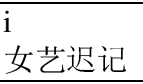 & $\begin{array}{l}\text { iu } \\
\text { 标超跳晓 }\end{array}$ & $\begin{array}{l}\text { im } \\
\text { 镰陕严甜 }\end{array}$ & $\begin{array}{l}\text { in } \\
\text { 变言千全 }\end{array}$ & $\begin{array}{l}\text { ip 摄接胁贴 } \\
\end{array}$ & $\begin{array}{l}\text { it } \\
\text { 别揭铁雪 }\end{array}$ \\
\hline $\begin{array}{l}\text { ia } \\
\text { 姐借写邪 }\end{array}$ & $\begin{array}{l}\text { ian } \\
\text { 命竞姓醒 }\end{array}$ & $\begin{array}{l}\text { iak } \\
\text { 逆迹壁狄 }\end{array}$ & $\begin{array}{l}\text { ien } \\
\text { 京警敬庆 }\end{array}$ & $\begin{array}{l}\text { ion } \\
\text { 胸穷 }\end{array}$ & $\begin{array}{l}\text { iok } \\
\text { 玉 }\end{array}$ \\
\hline $\begin{array}{l}\text { i } 5 \\
\text { 茄靴 }\end{array}$ & $\begin{array}{l}\text { ion } \\
\text { 凉墙向腔 }\end{array}$ & $\begin{array}{l}\text { iok } \\
\text { 略雀脚弱 }\end{array}$ & $\begin{array}{l}\text { iun } \\
\text { 软熏 }\end{array}$ & $\begin{array}{l}\text { iem } \\
\text { 壬任 }\end{array}$ & $\begin{array}{l}\text { iep } \\
\lambda\end{array}$ \\
\hline $\begin{array}{l}\text { u } \\
\text { 补舒府紫 }\end{array}$ & $\begin{array}{l}\text { ui } \\
\text { 来杯嘴泪 }\end{array}$ & $\begin{array}{l}\text { un } \\
\text { 寒搬穿损 }\end{array}$ & $\begin{array}{l}\text { ut } \\
\text { 钵阔律戌 }\end{array}$ & $\begin{array}{l}\text { iun } \\
\text { 薰 }\end{array}$ & \\
\hline $\begin{array}{l}\mathrm{m} \\
\text { 唔 }\end{array}$ & $\begin{array}{l}\text { 五误仵 } \\
\text { 等 }\end{array}$ & & & & \\
\hline
\end{tabular}

Notes:

1. PZD has six vowel phonemes: $[a, \mathfrak{e}, \mathrm{i}, \varepsilon, \mathrm{\jmath}, \mathrm{u}]$. Apart from [e], all can be used as rimes. Also, when [u] exists in front of $\mathrm{y} / \mathrm{k}$, the actual pronunciation is [o], which is complementary distribution with $[\mathrm{u}]$. Therefore we do not treat [o] as a phoneme.

2. $[\mathrm{a}, \mathrm{e}]$ as nucleus can practically have all kinds of coda, but $[\mathrm{e}]$ cannot form a rime independently. [a, $\mathrm{e}]$ are contrasted not only in the tongue position, but also in the time length, as the latter is heard to be shorter.

3. $[\mathrm{u}]$ can be nucleus and coda, but cannot serve as glide. As nucleus it can combine with $[-\mathrm{i},-\mathrm{n} / \mathrm{t},-\mathrm{n} / \mathrm{k}]$, but with $[-\mathrm{n} / \mathrm{k}]$ it changes to [o].

4. No [y]. Characters pronounced as [y] in Cantonese are usually derounded to [i] or backed to [u]. This is very similar to Hakka.

5. The rimes [ $\varepsilon \mathrm{\eta}, \varepsilon \mathrm{k}$, iun, iuy, iuk] involve only very small numbers of characters, usually with $\mathrm{k}, \mathrm{h}, \mathrm{\eta}$ or zero onset.

6. $[\mathrm{m}, \mathrm{y}]$ are syllablized nasal rimes and exist only independently.

\section{Tones}

\begin{tabular}{|l|l|l|}
\hline High Level (Yingping 阴平) & 33 & 多资煎光 \\
\hline Low Level (Yangping 阳平) & 11 & 麻兰背半 \\
\hline Rising (Shamgsheng 上声) & 35 & 可保女眼 \\
\hline Departing (Qusheng 去声) & 53 & 住号电锻 \\
\hline High Entering (Yinru 阴入) & $55 \nearrow$ & 甲湿割彻 \\
\hline Low Entering (Yangru 阳入) & 55 & 十活穴略 \\
\hline
\end{tabular}

Note:

Entering tones are checked syllables. The Low Entering is comparable to Cantonese 55, and the high Entering is even higher, ending in a pitch higher than 5 . We indicate this with an arrow $\nearrow$.

\section{Middle Chinese Origin of PZD}

We compare the onsets, rimes and tones of the PZD with that of Middle Chinese (MC) in order to know the origin of the PZD.

\section{Onsets}

Labials. [p] are mostly from the MC bilabial onset (帮), $\left[\mathrm{p}^{\mathrm{h}}\right]$ from Pang (浐) and Ping (并);but in exceptional cases MC Bing characters are read as [p], such as“皆 [pei11]”. Besides, a few characters may come from the Fei group, such as “斧 [pu35], 捧 [pon35]”

[m] are from the MC onsets Ming (明) and Wei (微), although a few characters from Wei may be pronounced $[\mathrm{v}]$ (see below).

[f] originated from the MC labiodental onsets Fei (非), Fu (敷), Feng (奉), as well as the closed rime characters of the velar fricative onset Xiao (晓), and a few characters from Qi (溪), such as “苦 [fu35], 宽 [fun33]"

[v] comes mostly from the MC zero onsets Ying (影), Yu (喻) and some from onset Xia (匣). Only a few are from Wei, such as “闻 [ven11], 物 [vet55]”. 
Dentals. $[t]$ is pronounced for the characters of MC Duan (端), but a few exceptions come from the Zhi (知) onset such as “啄玩[tok55 $\left.{ }^{\prime}\right]$ ”.

[th] from Tou (透), Ding (定), 1 from Lai (来) and most of Ni (泥). However, some Ni characters followed by [i] may be pronounced with [n].

Sibilants. PZD has only [ts, tsh, s]. They are pronounced with a position between dental and alveolar, similar to Cantonese and Hakka. The MC correspondences are also similar to Cantonese.

[ts] are from MC unvoiced Zhi (知), Jing (精), Zhao (照). Only a few characters are from unvoiced characters such as “秩 [tset55], 召 [tsiu33]”.

$\left[\mathrm{ts}^{\mathrm{h}}\right]$ are mainly from MC unvoiced Zhi (彻), Qing (清), Chuan (穿), as well as from the voiced onsets Cheng (澄), Cong (从), Chuang (床), as well as some characters from Xie (邪) such as “谢” [tshia53].

[s] are from MC Xin (心), Shen (审), Shan (禅), and a few are from Xie (邪).

Velar, glottal. [k] is pronounced for most from characters of MC onset Jian (见).

$\left[\mathrm{k}^{\mathrm{h}}\right]$ for most from characters of MC onsets Qun (群) and some from Qi (溪)

[n] for most from characters of MC onset $\mathrm{Yi}$ ( 疑).

[n] from onset MC Yi (疑) and some from onset Ri (日).

[h] from MC Xiao (晓). And most of Qi (溪),

[j] from most characters of Ri (日), Ying (影) and Yu (喻); as well as some characters of Xia (匣).

[ǿ] from characters of MC Ying (影).

From the above, we can conclude some characteristics of PZD:

All MC voiced stops and affricated are mostly aspirated after devoicing, like the Hakka dialect.

The three MC Onset groups Zhi (知), Jing (精) and Zhao (照) all merged into one set of silbilant [ts, ts , s].

The onset Xie (邪) can be ts, tsh or s. Cantonese pronounces it as [ts, tsh] and Hakka mostly [s]. Thus it behaves as an intermediate between both dialects.

$[\mathrm{v}]$ is pronounced in place of $[\mathrm{w}]$, but the characters involved are mostly those with $[\mathrm{w}]$ as onsets in Cantonese, showing that it is closer to Cantonese.

\section{Rimes}

In order to have a clear view, the rime and the MC origin are listed in tables.

Table 1

Simple Vowels and Diphthongs

\begin{tabular}{|c|c|c|c|}
\hline Rime & MC rime group /Grade & Rime & MC rime group /Grade \\
\hline [a] & Jia (假) /II and part of III & [i] & $\begin{array}{l}\text { Zhi (止) /III, open } \\
\text { Yu (遇) / Part of III }\end{array}$ \\
\hline$[\mathrm{u}]$ & $\mathrm{Yu}($ 遇) /I and Part of III & [0] & $\begin{array}{l}\text { Guo (果)/ I } \\
\mathrm{Yu}(\text { 遇) / Part of III }\end{array}$ \\
\hline [ai] & $\begin{array}{l}\text { Xie (蟹) / II and part of I, } \\
\text { open }\end{array}$ & {$[\mathrm{au}]$} & Xiao (效) / I and II. \\
\hline [iu] & Xiao (效) / III and IV & [i门] & $\begin{array}{l}\text { Guo (果)/ III } \\
\text { Xie (蟹) / part of I, open }\end{array}$ \\
\hline [ia] & Jia (假) / part of III & [ui] & $\begin{array}{l}\text { Xie (蟹) / III and IV, closed } \\
\text { Zhi (止) / III, closed }\end{array}$ \\
\hline [вi] & Xie (蟹) / III and IV, open & [eu] & Liu (流) / I and III \\
\hline
\end{tabular}


Table 2

Rimes With Nasal and Stop Codas

\begin{tabular}{|c|c|c|c|}
\hline Rime & MC rime group /Grade & Rime & MC rime group /Grade \\
\hline [am/ap] & Xian (咸) / I and II, open & [im/ ip] & Xian (咸) / III and IV, open \\
\hline [em/еp] & Xian (深) / III & [an/ at] & $\begin{array}{l}\text { Shan (山) / I and II, open } \\
\text { Xian (咸) / III, closed }\end{array}$ \\
\hline [in/ it $]$ & Shan (山) / III and IV, open & {$[\mathrm{en} / \mathrm{et}]$} & Zhen (臻)/ I and III \\
\hline [un/ ut] & $\begin{array}{l}\text { Shan (山) / I (velar), open } \\
\text { Zhen (臻)/ part of I, closed }\end{array}$ & {$[\mathrm{ay} / \mathrm{k}]$} & Geng (梗) / II, open \\
\hline$[\varepsilon \mathrm{y} / \varepsilon \mathrm{k}]$ & Zeng (曾) / I and III, open & {$[\mathrm{en} / \mathrm{ek}]$} & $\begin{array}{l}\text { Zeng (曾) / I and III, open } \\
\text { Geng (梗) / III and IV, open (literal) }\end{array}$ \\
\hline [oy/ok] & Tong (通) /I and III & {$[\circ \mathrm{y} /$ วk] } & $\begin{array}{l}\text { Dang (宕) / I and part of III, open } \\
\text { Jiang (江) / II }\end{array}$ \\
\hline [iay/ iak] & Geng (梗) / III and IV, open (colloquial) & [iəy/ iək] & Dang (宕) / most of III \\
\hline
\end{tabular}

From the above, we can summarize the characteristics of the rimes of PZD as the following:

1. The MC Chinese nasal codas $[\mathrm{m}, \mathrm{n}, \mathrm{y}]$ and the corresponding entering codas $[\mathrm{p}, \mathrm{t}, \mathrm{k}]$ are well preserved and correspond well with the rime groups, like Cantonese.

2. Literal and colloquial readings of the Geng rime group exist, as in most Hakka and Yue dialects (Lau, 2007), but unlike Hakka, they have $[-\mathrm{n} / \mathrm{k}]$ as codas.

3. Grade I and II are not differentiated in the Xiao rime group, similar to Hakka and unlike Cantonese.

4. As PZD has no medial [-u-], most characters from the closed mouth conflate into open mouth.

\section{Tones}

The four tones in MC develop into six tones in the PZD. The Level, Rising and Entering tones are divided into Upper and Lower (Yin and Yang), but the Departing tone is an exception. We will go into the details in the section of Tonal characteristics of PZD.

\section{Characteristics of the PZD}

\section{Onset and Rime Characteristics}

From the above description, PZD has both Hakka and Yue characteristics. First, we look into the Yue characteristics (Zhan, 2004):

1. Most MC Wei (微) onsets are now [m];

2. Contrast in the vowels $[\mathrm{a} / \mathrm{e}]$;

3. Codas of the Zeng(曾) and Geng (梗) rimes are $\mathrm{n} / \mathrm{k}$;

4. Grade III and IV of Xie (蟹) are [ei] to clearly differentiate from Zhi (止);

5. Nucleus of Grade III and IV rimes of MC rime groups Xiao (效), Xian (咸), Shan (山) is [i].

Then Hakka characteristics (Lau, 2004):

1. All MC voiced stop and affricate onsets are devoiced to aspirated onset;

2. Absence of $[y]$;

3. Both Grade I and II of Xiao (效) rime groups are pronounced as [au];

4. [i] can be used as glide, e.g. ia, iay, iak.

But in addition, there are obvious characteristics of the Donnguan-Baoan Yue dialect (DBYD) (Zhan, 2004): 
1. Grade I of the Xie (蟹) Rime group is pronounced [ui];

2. Grade I characters of the Shan Rime group with Jian group onsets has [un/t];

3. Grade III of Zeng (曾), III IV of Geng (梗) are [ey/k].

Apart from these, there are some characteristics commonly shared by dialect in eastern Shenzhen:

1. $\mathrm{n} / \mathrm{l}$ are conflated, most $\mathrm{MC} \mathrm{n}$ onsets are now $\mathrm{l}$;

2. Absence of glide $[\mathrm{u}]$ : the original $[\mathrm{u}]$ disappeared.

Although there are lots of Hakka and Yue characteristics, we can easily conclude that it is a DBYD judging from the rime characteristics.

PZD resembles Hakka in the way that it aspirates all voiced MC onsets, which is a major characteristic of the Hakka dialect. But there are also some Non-Hakka dialects with this characteristic, such as the Yue dialect of the Wuhua (吴化) area. In the Linguistic Atlas of China (1989), these Yue dialects are marked for this characteristic and scholars explain that it is a result of language contact (Zhan, 2004). The absence of [y] is also characteristics of most Hakka dialects, but it is also shared by many Yue dialects in western Guangdong. Also, some Hakka dialects also have [y] in northern Guangdong (Gan, 2010).

In an area where Hakka people dominate, it is not easy for PZD to get characteristics of the DBYD. We can only say that it is retention. Apart from these, in the basic vocabulary, we also find that glosses like "look, give, that" follow that of Yue, not Hakka.

As PZD is a Yue dialect, we can easily interpret that those characteristics common with Hakka are actually results of language contact.

\section{Tonal Characteristics of PZD}

PZD has six tones, which resembles Hakka superficially. However, when we investigate into the Chinese characters they contain, we discover that they have different contents, showing that this is a case of deeply-rooted language contact. The following shows the MC origin of the tones in PZD.

Table 3

Correspondence of PZD Tones With Middle Chinese Tones

\begin{tabular}{|c|c|c|c|}
\hline Tone in Middle Chinese & Conditions & Tone in PZD & Examples \\
\hline \multirow[t]{2}{*}{ Level } & Unvoiced & Upper Level 33 & 多巴乘天康 \\
\hline & Voiced & Lower Level 11 & 驼爬怀田杭 \\
\hline \multirow[t]{9}{*}{ Rising } & Unvoiced & Rising 35 & 左古把产想 \\
\hline & Sonorant & Rising 35 & 雅五女米眼 \\
\hline & & Lower Level 11 & 我马惹暖养 \\
\hline & & Upper Level 33 & 鲁吕奶咬痒 \\
\hline & & Departing 53 & 哪牡染朗壤 \\
\hline & Voiced & Departing 53 & 祸部受善尽 \\
\hline & & Lower Level 11 & 舵坐舅像凤 \\
\hline & & Upper Level 11 & 社簿巨稻旱 \\
\hline & & Rising 35 & 辅跪伴篆荡 \\
\hline \multirow[t]{2}{*}{ Departing } & Unvoiced & Lower Level 11 & 过价去印众 \\
\hline & Voiced & Departing 53 & 磨路预让命 \\
\hline \multirow[t]{2}{*}{ Entering } & Unvoiced & Upper Entering $55 \nearrow$ & 八设脱穴妾 \\
\hline & Voiced & Lower Entering 55 & 拔舌夺学捷 \\
\hline
\end{tabular}

In PZD, MC tones differentiated are divided into Upper/Lower (Yin/Yang) according to the voicing. In 
general, Upper (Yin) has a higher tone pitch, but the situation in the MC rising tone is very complicated. The unvoiced MC rising are always rising (35) in PZD, which looks regular, but problematic with sonorant and voiced onsets.

Yue, Hakka and Eastern Gan all have about 2/3 of the MC voiced characters pronounced as Departing, and the rest of them go to either an independent Upper-Shang in Cantonese, or combines to the Upper-Ping in Hakka and Gan (Lau, 2003). However, the case is totally different in PZD. Of the 107 characters recognized by the informant, only 54 are pronounced the Departing tone, which is barely one half. The rest go into three directions: 21 as Lower Ping, 18 as Shang, and 14 as Upper-Ping.

We interpret this as following: although Lower-Ping (11) contains most characters from the MC Ping characters with voiced and sonorant onsets, there are also characters from voiced Shang and sonorant (correspond to those in Cantonese Lower Shang), and also a lot of MC unvoiced Departing (correspond to those in Cantonese Upper Departing). In other words, PZD tone 11 is actually a combination of characters of Cantonese 11, 13 and 33.

For MC sonorant belonging to the rising tone, we find that among the 82 characters, more than half of them are now read as 35. These are mostly basic glosses, such as "five (五), female (女), ear (耳), rain (雨), old (老), two (两), eye (眼)”. Therefore we are sure that 35 is the origin tone for the MC rising tone characters. Those read as Upper Level and Departing add to about $15 \%$, which are similar to Hakka, and should be the result of language contact. About 35\% are read as Lower-Level, of which some of them are basic, such as “horse (马), buy (买), tail (尾), have (有)".

MC sonorant onsets of the Rising tone are divided into two major categories: commonly used characters such as “冷暖懒满养惹有” are merged into Upper-Ping, while the rest (majority) remain as Rising. In most Yue dialects, MC sonorant onset of the Shang tone seldom split, but PZD is an exception. Also, about 15\% of the rest, such as “鲁吕奶咬痒” read as Upper-Level, “哪生染朗壤” read as Departing, is a total imitation of Hakka.

MC voiced onsets of the Rising tone, similar to the sonorant, also go into four tones. About half of them such as “祸部受善尽” go to Departing, which is normal, as 2/3 of the MC voiced rising go to Departing in the neighboring Hakka and Yue dialects. About 20\% of them like “舵坐舅像凤” are read as 11 (Lower-Level), which correspond to Lower-Rising in Cantonese, is a retention of the "Rising" tone. These have nothing to do with the language contact with Hakka.

About 18\%, such as “趾伴管荡” are read as Rising, 13\% such as “社簿巨稻旱” are pronounced Upper-Level. As these are also Rising and Upper-Level in Hakka, is a result of imitation due to long term language contact.

From these tone comparisons, we can see that PZD is influenced deeply by Hakka which is an exceptional case for a Yue dialect.

\section{Comparison With Weitou Dialect in Hong Kong and the Dapeng Dialect in Shenzhen}

Both Weitou and Dapeng dialect are members of the DBYD subgroup (Zhang \& Chong, 2003; Lau, 2011), which share many phonological features with PZD. Moreover, they have also similar glosses.

The Weitou dialect in Northern New Territories of Hong Kong is relatively unaffected by the Hakka dialect. The MC voiced characters are devoiced and the aspiration rules follow those of Cantonese; namely MC Level and Rising are aspirated, Departing and Entering are unaspirated. The glide $[\mathrm{u}]$ is intact and there is no 
glide [i]. The rime structure has also been simplified, with codas -n/t conflated into $\mathrm{y} / \mathrm{k}$ (Sagart, 1982; Zhuang \& Chong, 2003). There are six tones, namely Upper-Level (13), Lower Level (11), Rising (35), Departing (22), Upper Entering (35) and Lower entering (22). In the Weitou spoken in Southern New Territories, the aspiration is the same, but the glide $[\mathrm{u}]$ is missing. However, conflation of codas did not occur. The tones are more or less the same, except that the Lover Entering is 55 (Zhuang \& Chong, 2003). When we look at the characters carefully, we can see that the Upper Level tone actually is a combination of Upper Level, Upper Departing and Lower Rising in Cantonese. We cannot see any influence of Hakka in the tones.

The Dapeng dialect in Shenzhen is very similar to the PZD on the whole, both phonologically and in the vocabulary. The devoicing patterns of MC voiced characters, like PZD, follow that of Hakka, meaning that they are all aspirated after devoicing. Absence of $[\mathrm{u}]$ as glide and no $[\mathrm{y}]$ as rime also resemble the neigboring Hakka dialects. The codas $[\mathrm{m}, \mathrm{n}, \mathrm{y}, \mathrm{p}, \mathrm{t}, \mathrm{k}]$ are kept as in Cantonese or Southern Weitou. Dapeng dialect has a set of rimes [ia, iay ,iak, is, ioy, ijk] which are in common with Hakka, but they only form a minority group, while

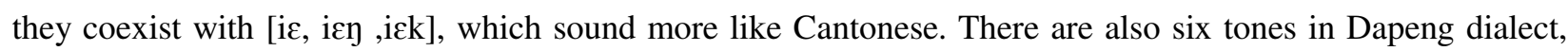
Upper-Level (33), Lower Level (11), Upper Rising (35), Lower Rising (13), Departing (53), Entering (55) (Lau, 2011).

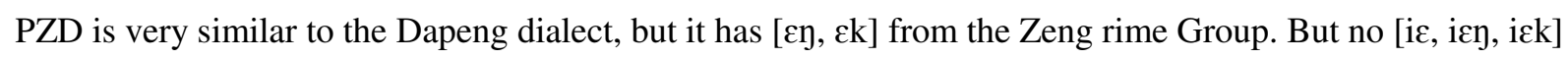
from the Geng rime group, as these are correspondingly read as [ia, iaj ,iak], which is same as Hakka. [iun] is also unique in Hakka, which is only borrowed to PZD but not Dapeng. This also shows that the PZD has received deeper influences than the Dapeng dialect.

In the tones, Dapeng is not affected in the tonal differentiation from MC. Both Level and Rising tones are split into upper and lower, with Level as 33 and 11, Rising as 35 and 13, in a pattern very similar to Cantonese. $2 / 3$ of MC voiced onsets of the rising tone go to departing tone as in Cantonese or Hakka, but 1/3 form an independent Lower-Rising tone, which is characteristic of Cantonese (Lau, 2003). The Departing tone also split into 33 and 53, quite similar to Cantonese. The Entering tone does not split. From this data, we cannot see any influence from Hakka during its tone formation.

In PZD, apart from the splitting of MC Level tones, the splitting of other tones differ a lot from other Yue dialects or Hakka dialects. We can found a lot of evidences of language contact.

\section{Discussion}

The PZD is a vanishing dialect. It existed as a dialect island for centuries and was trapped in an environment of Hakka speakers. Its speakers insisted to speak their "ancestral tongue", educating their children not to forget their origin. This effort made then to maintain their dialect into the 21st century.

After long term contact, PZD still possesses the major characteristics of DBYD, and to a large extend quite similar to the Dapeng Dialect not far away from it. However, the erosion from Hakka is much more serious than the Dapeng dialect, in the onsets, rimes, and even tones. This forms an interesting picture of language contact between Chinese dialects.

As the society continues to evolve in Shenzhen, the number of PZD speaker quickly diminishes, and the younger generations use Hakka as their home language. Because of urbanization, the younger people have finished the language shift. While they speak with the majority around themselves in Hakka, they must also learn Mandarin and Cantonese. PZD, their ancestral tongue, became a useless language.

This study not only fill a blank for the languages in Shenzhen, but also shows how a weaker dialect can 
exist as an dialect island for centuries, and how they strived for survival by adapting themselves in an energetic way. It also helps to clarify the evolution of different Yue dialects.

\section{Conclusion}

We conclude that the PZD is a Yue dialect belonging to the Baoan-Dongguan group heavily affected by the Hakka dialect. PZD is now a vanishing tongue, with only about 10-20 speakers of above 75 years old. This report not only provides an evidence of its existence, adding it as an extraordinary member to the Yue Dialect Group, but also shows how a Yue dialect can be affected by the surrounding Hakka dialect, which is a rare case in Guangdong.

\section{References}

Baoan County Regional Data Compilation Committee. (1997). Baoan County record (宝安县志). Guangzhou: Guangdong Remin Publishers.

Chinese Academy of Social Science, Australian Academy of Science and Humanities. (1988). Linguistic Atlas of China. London: Longmans.

Gan, Y. E. (2010). Distribution of dialects in Guangdong (广东省方言的分布). Academic Research (学术研究), 9, 140-150.

Lau, C. F. (2003). The evolution pattern of voiced Shang tone in Yue dialects from a comparison of neighboring dialects (从方言 比较再探讨粤语浊上清化的模式). Zhongguo Yuwen (中国语文), 296, 432-438

Lau, C. F. (2004). The Indigenous Hakka dialect of Hong Kong-A vanishing voice (香港原居民客家话一一个消失中的声 音). The Chinese Language Society of Hong Kong.

Lau, C. F. (2007). A study on the origin of literal and colloquial pronunciation discrepancies in the Geng rime group of Cantonese from dialect comparisons (从方言比较看粤语梗摄三四等字文白异读的由来). Fangyan (方言), (3), 311-318.

Lau, C. F. (2011). Looking at the contact relationship between Yue and Kejia Dialects from the example of the Dapeng dialect (从 深圳大鹏话看粤语和客家话的接触关系). Shenzhen, In Southern Linguistics (南方语言学), Special Issue for The Celebration of the $80^{\text {th }}$ Birthday of Professor Zhan Bohui. Dialect Study Centre, Jinan University, pp. 42-45.

Sargart, L. (1982). Phonology of a Cantonese dialect in the New Territories, Kat Hing Wai. Journal of the Hong Kong Branch of the Royal Asiatic Society, 22, 132-160.

Shenzhen History Working Committee. (1996). A brief account of the 19 townships in Shenzhen (深圳十九镇简志). Shenzhen: Haitian Publishers.

Zhan, B. H. (2004). An introduction to the Yue dialects of Guangdong (广东粤方言概要). Guangzhou: Jinan University Publishers.

Zhuang C. S., \& Chong, S. H. (2003). Dialects of the New Territories of Hong Kong (香港新界方言). Hong Kong: Commercial Publishers. 